EETP Vol. 16, 2021, №. 2(60)

ISSN 1896-2327 / e-ISSN 2353-7787

DOI: $10.35765 /$ eetp.2021.1660.07

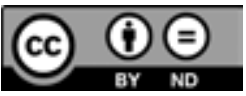

Nadesłano: 8.05.2021

Zaakceptowano: 20.06.2021

Sugerowane cytowanie: Rosati N. (2021). Pre-primary and Primary Teacher Formation in Italy: Contents and Methodology, "Edukacja Elementarna w Teorii i Praktyce”, vol. 16, nr 2(60), s. 89-98. DOI: 10.35765/eetp.2021.1660.07

\author{
Nicoletta Rosati \\ ORCID: 0000-0002-2458-9820 \\ Libera Università Maria SS. Assunta di Roma, Italia
}

\title{
Pre-primary and Primary Teacher Formation in Italy: Contents and Methodology
}

\section{Formacja nauczycieli przedszkolnych i szkół podstawowych we Włoszech: treść i metodologia}

\begin{abstract}
KEYWORDS ABSTRACT
pre-primary and This contribution aims to describe the formation process of pre-priprimary school, mary and primary teachers in Italy. Some brief historical aspects about degree course, the development of the pre-primary and primary teacher curriculum curriculum, are described to better understand how the formation process has laboratories, changed in Italy in the last twenty years. A university degree course professional teacher is now the basic requirement to become a teacher at pre-primary and training primary level. In the description of the different parts which make up the Italian degree course curriculum, some pedagogical reflections are presented with their didactical and methodological implications.
\end{abstract}

\section{SŁOWA KLUCZE ABSTRAKT}

przedszkole i szkoła podstawowa, studia dyplomowe, program nauczania, laboratoria, doskonalenie zawodowe nauczycieli
Celem artykułu jest przedstawienie procesu formacji nauczycieli przedszkolnych i szkół podstawowych we Włoszech. Aby lepiej zrozumieć, jak zmienił się proces kształcenia nauczycieli we Włoszech w ciągu ostatnich dwudziestu lat, opisano kilka krótkich aspektów historycznych dotyczących rozwoju programu nauczania dla nauczycieli przedszkoli i szkół podstawowych. Studia uniwersyteckie są obecnie podstawowym wymogiem, który pozwala zdobyć uprawnienia do pracy jako nauczyciel na poziomie przedszkolnym i podstawowym. W opisie różnych części składających się na program nauczania studiów włoskich przedstawiono niektóre refleksje pedagogiczne z ich implikacjami dydaktycznymi i metodologicznymi. 


\section{Introduction}

In this paper, we will deal with the formation of pre-primary and primary teachers as one topic as the formation of both pre-primary and primary teachers is the same in Italy. This has not always been the case, however, as the formation process has changed in the last fifteen years.

Until 2001, students who had completed the last year of a special high school for teaching, called "Istituto Magistrale" (Insitute for Teachers) could teach in pre-primary and primary school without any additional teaching certification. In 1998, the Ministry of Education instituted a university degree course to certify pre-primary and primary teachers, eventually replacing the Istituto Magistrale diploma. After 2001, the Istituto Magistrale was eliminated and all pre-primary and primary teachers were trained in the university degree programme.

Between 1998 and 2010, the first four-year university degree course, called Science of Primary Education, was instituted for teachers. For the first two years, both future pre-primary and future primary teachers shared the same curriculum. However, from the third year on the curriculum was different for each scholastic level. Upon the completion of the fourth year, two different degrees were conferred: a degree in preprimary education or a degree in primary education.

In 2010, the university degree courses for pre-primary and primary teachers changed to a five-year course. Since then, students who want to become pre-primary or primary teachers follow the same curriculum and obtain a degree which certifies them to teach at both levels.

To be enrolled in the Science of Primary Education degree programme, the candidate must have obtained a high school diploma. The Humanistic studies presented in the lyceum of Human Science or in the Classic Studies Lyceum are the most suitable preparation for the degree course to become teachers at the pre-primary and primary level.

\section{Curriculum Content}

The curriculum which the students follow to become teachers at the pre-primary and primary levels has changed over the years. When the degree course was extended to a four-year course, the curriculum for the first two years consisted of introductory teaching courses on general pedagogy, general psychology, general didactics, and general anthropology and sociology. In the second two years, the subjects of the curriculum were different according to the scholastic level the students were training for. Future pre-primary school teachers studied pedagogy and didactics of games, 
techniques of observation of young children, and health and hygiene, while future primary teachers studied the teaching of mathematics, Italian, foreign language, curriculum design, etc.

The degree course included forty-two exams and at least 400 hours of professional teacher training.

Nowadays, the degree course consists of a five-year course without any variation in the curriculum for pre-primary and primary teachers. The students of this course receive one degree to teach both at the preschool level and at the primary level, as mentioned above. The disciplines of the previous course and of the present course can be divided into four areas of study, corresponding to the different scientific sectors needed to prepare future pre-primary and primary teachers. These four areas are:

1. Formation for the role of teacher

2. Pre-primary and primary teaching content

3. Laboratories

4. Professional teacher training

\section{Formation for the role of teacher}

The profession of teacher belongs to the category of professions based on the concept of helping, which also include health care professionals, social workers, psychologists and so on.

This kind of professional involves the education and formation of individuals, which consists of two basic processes: $e$-ducere and in-struere. E-ducere is a Latin word that means "bringing out one's talents, dreams, expectations, objectives and life plans". In-struere is another Latin word that means teaching someone a subject or skill. Both of these two processes characterize the role of the teacher and his function of docere, or teaching.

Education and instruction are not synonymous, but instead refer to different processes that interrelate in the function of teaching. This means that a teacher needs to consider all the different dimensions that compose the pupil's or student's personality: the social-relational, the cognitive, the physical, the emotional-affective, the ethical, the aesthetic, the playful, and the spiritual and religious. A good teacher will take into account all of the various dimensions that make up a child's personality. This style of teaching will see each child in virtue of his uniqueness, his originality and his personal freedom. The pedagogical consequences of this concept are that every individual possesses his own special mould according to which he must be guided while respecting his own individual nature. 
The respect for the individual nature of every child requires that the teacher know every aspect of the child in terms of the family and social context in which he lives. Respect for the child results in the teacher becoming a model for the child, but not shaping the child in the teacher's own image.

To achieve this, a future teacher follows his university study path as an opportunity for personal growth as well as a cultural and professional formation. Every authentic educational process requires the willingness on the part of the educator to educate himself while educating others. This concept has become more popular in the past forty years under the pressure of the Critical Pedagogy Movement of Paulo Freire (Freire 1971; Catarci 2016).

The relationship with the others is a fundamental element of the educator's identity. The relationship also manifests itself as a form of complex communication, in which feelings and emotions intertwine in profoundly personal ways. Emotionality and affectivity are integrated into the psychic structure of the human being and the relationship with reality results in the development of relational skills (Cervi- Bonesso 2008).

With the ability to enter into relationships with others and with the world comes the opportunity to know, to understand, to co-exist, to interact, to collaborate and to cooperate (Rosati 2015). What is needed for the formation of a teacher is the development of social skills and the acceptance of others and their differing points of view on the same problem. The teacher must possess leadership qualities and be prepared to negotiate conflict. Furthermore, the teacher must demonstrate a collaborative attitude at work, a synergy of action and an ability to control the group as well as an ability to assess student work and evaluate her or his own work.

The disciplines for the formation of the teacher according to the above-mentioned profile are: 2education, general sociology, theology, sociology of education, developmental psychology, and child psychopathology.

\section{Pre-primary and primary teaching content}

A teacher must not only be formed from a cultural point of view, but also be prepared to teach specific subjects at a proficient level .This is why the curriculum for pre-primary and primary teachers includes disciplines such as math foundations and the teaching of maths, natural science, Italian history and the teaching of history, pre-primary and primary education, assessment, contemporary Italian literature, methods and techniques of physical education, artistic expression, health and hygiene, pedagogy and didactics of games, cooperative learning, chemistry and the teaching of chemistry, the Italian language and the teaching of the Italian language, children's 
literature, physics and the teaching of physics, special education, experimental education, music and the teaching of music. In September 2010, the Italian government issued a Ministerial Decree (D.M.n.249) listing the subjects from which each university could choose as part of the degree curriculum for pre-primary and primary teachers. The list of disciplines included in the Ministerial Decree are based on the National Guidelines for the pre-school and primary school curricula.

The National Guidelines for pre-school are organized in a general section where the teacher is reminded of the importance of pre-school instruction that promotes the development of identity, autonomy, competence and active citizenship for children between the ages of three and six. The general section is followed by guidelines for educational activities based on pre-discipline contents, as we cannot refer to the teaching of disciplines when dealing with children of this age group.

Children are naturally inquisitive about knowing the world around them. They pose many concrete questions about their environment and about the events in their lives. Many of these questions represent their motivation for understanding the meaning of the life that surrounds them. Proceeding in this way, children learn to build knowledge, but they do not yet systematize this knowledge into categories. Disciplines are categories of knowledge, and these categories are beyond a child's understanding. The competencies that a child develops during pre-school are comprehensive and unitary in nature and not yet specific or specialized, consequently, the pre-school curriculum is not composed of disciplines, but rather "campi di esperienza" (fields of experience). These fields of experience are: oneself and the others, the body and movement, images, sounds and colours, words and discourse, and knowledge of the world.

Oneself and the others: the child learns to reflect on his feelings and experiences and develop self-awareness. The child learns to interact with adults and with peers and to recognize the most important symbols of his culture and his environment.

The body and movement: the child gains awareness of his body and uses it as a tool to gain knowledge of himself in the world. Movement is the first determinant for learning: searching, discovering, playing, jumping and running at school are all a source of physical and psychological wellbeing.

Images, sounds and colours: the child expresses thoughts and emotions using his imagination and creativity. Art guides this inclination by cultivating an appreciation for beauty and a sense for the aesthetic. The child's exploration of different kinds of material allows him to live his first artistic experiences influencing all further learning. The language available to the child, such as voice, gestures, drama, sound, music, handling of materials, graphic-pictural experiences and the mass-media are to be discovered and cultivated. All the above are necessary for developing an appreciation for beauty, self-awareness, as well as an awareness of others and of the real world. 
Words and discourse: language is an essential tool to communicate and know, and to express more complex and well-defined thought. This occurs thanks to a dialogue with others, through concrete experiences and observation. Pre-school is responsible for promoting the mastery of the Italian language while respecting the mother tongue of every child regardless of his country of origin. The mother tongue is part of each child's identity, but the knowledge of other languages moves him towards encounters with new worlds and new cultures.

Knowledge of the world: this field is composed of two sub-fields: objects, phenomena, and living beings and space and numbers. The child continually explores his environment and learns to reflect on his own experiences, describing them, representing them, and re-organizing them according to different sets of criteria. This process creates the basis for the future elaboration of scientific and mathematical concepts, which will be presented as part of the primary school curriculum. Curiosity and questions about natural phenomena, about oneself, about living organisms, stories and traditional tales and games with mathematical references all can be used to find explanations for the real world and how it works.

In the primary school curriculum, content becomes structured disciplines. The main goal of a primary school education is to impart knowledge to help develop basic skills and competencies for the fulfilment of each individual pupil. From its beginnings, primary school has promoted a course of activities which allows every pupil to assume an active role in his own learning. This is achieved by best developing his inclinations, by expressing his curiosity, and by recognizing and coping with difficulties. In this way, the pupil gains greater and greater self-awareness and begins to build his very own life plan. The school proposes situations and contexts in which the pupil can reflect and seek to understand the world and himself. He becomes aware of the fact that his body is an asset which requires his care. The pupil finds stimuli for developing analytical and critical thinking. He learns to learn, and he develops his imagination. He tries to measure up with others in his search for meaning, and he reflects on the reasons for and the consequences of his choices.

The primary school promotes cultural and social literacy, that is, reading, writing and arithmetic, by way of language acquisition and codes that constitute the structure of our culture. This occurs in a broader horizon open to other cultures with which we live and to the conscious use of new media.

In primary school, boys and girls are given the opportunity to develop cognitive, emotional, affective, social, physical, ethical and religious dimensions, and to acquire fundamental knowledge.

The primary school presents itself as a formative organ which, by using the knowledge that characterizes each discipline, allows for the exercise of different cognitive 
styles and the development of reflective and critical thinking. In this way, informed and responsible citizens are formed at all levels of society, from the local to the European.

The learning environment of primary school is characterized by several pedagogical and educational principles:

appreciate the pupil's experience and knowledge in order to anchor new content to this knowledge;

- carry out appropriate actions as regards diversity so that this does not become inequality;

- encourage exploration and discovery to foster a desire for a thirst for new knowledge;

- support collaborative learning;

- promote an awareness of one's learning styles;

- realize educational activities in the form of laboratories.

The concrete realization of the above-mentioned principles is carried out through the teaching of disciplines such as Italian, the English language, another European language, history, geography, mathematics, science, music, figurative art, physical education, technology, and religious instruction or an alternative discipline. It is important to note that for each discipline regarding the school curriculum, future teachers should know the content and the methodology for teaching that content. This can explain the different disciplines studied in the degree course for the future pre-primary and primary teacher. Future teachers need to be well-versed in children's literature, history, music education, hygiene, basic mathematics, didactics of motor skills, foreign language teaching, geography, government and civics, language acquisition, paediatrics, special education and didactics, Italian grammar, Italian language teaching, pedagogy and didactics of games, teaching, etc.

\section{Laboratories}

The laboratories represent an important part of the teacher training curriculum. They continue to be the place where future teachers can learn how to combine the theoretical content of the disciplines with the practical aspects of teaching. Students can attend laboratories such as learning to read and write, handicrafts, psychomotricity, didactics of mathematics, didactics of the Italian language, foreign language learning, course design and curriculum planning, etc.

The definition of laboratory derives from the medieval Latin word laboratorium which comes from the Latin verb laborare, meaning to work. In the laboratory, in fact, students work to construct knowledge and plan activities. In laboratories, student 
teachers learn how to transform abstract and theoretical knowledge into concrete and practical activities and course plans. This concept of laboratory is not limited to the traditional idea of a science lab or chemistry lab or art lab, but rather is a conception of structural design called laboratorial didactics.

Laboratorial didactics are characterized by:

the construction of knowledge and not a reproduction of it;

the use of authentic activities;

the context that provides the opportunity to learn how to apply knowledge;

the opportunity to generate new ideas and express creativity;

the use of cooperative learning;

practical and situated learning;

knowledge and know-how.

During the degree course the future teachers learn not only to transform theoretical knowledge into practical activities for children, but also to plan, construct and organize a school laboratory.

The concept of a school laboratory for children was explored and developed by Bruno Munari, in the Pinacoteca of Brera, Milan, in 1977. Bruno Munari, professor of Developmental Psychology at the University of Geneva, based his method on the didactical principle that states that teachers "are not to say what to do, but only how to do it". Munari was influenced by Dewey's ideas that placed the child at the centre of his learning. Munari's method focuses on a child's doing, as Munari maintained that when a child does something, he is able to express himself freely, without being influenced by adults. In this way, a child becomes independent and learns to solve problems by himself. For Munari, a laboratory for children is a place to express creativity, acquire knowledge, explore and discover on his own through the use of games (Munari 2017). The laboratory is a place that supports doing in order to understand, where "mental gymnastics" are done and knowledge is built. Munari's laboratory is a meeting place for education, formation and collaboration (Munari 1996). It is a space to develop the ability to observe with one's eyes and hands, to learn to look at reality with all the senses and to continue to learn. It is a place that stimulates "creative design thinking" from earliest childhood (Munari 2006).

As a result of Munari's experience with laboratories, the pre-primary and primary teachers' degree course laboratories offer a unique opportunity to learn how to involve children in active learning based on their need to explore, discover, and understand the world around them. 


\section{Professional teacher training}

An important part of the degree course curriculum to become a pre-primary and primary teacher is represented by teacher training. Starting from the second year of the degree course until the fifth year, the students go to pre-primary and primary school to do a teaching practicum.

During the second year, student teachers spend 25 hours in a pre-primary classroom and 25 hours in primary classroom observing the class and assisting the teacher. The main objective of this experience is to raise awareness of the value and role of the teacher. Another 50 hours is dedicated to monthly meetings with a mentor to discuss the salient points of their in-class experience.

During the third year, student teachers spend 35 hours in a pre-primary classroom and 35 hours in a primary classroom where they learn methods and didactical techniques. The main objective of this third-year experience is to acquire communicative competencies in teaching. Another 55 hours is dedicated to monthly meetings with a mentor to learn how to organize teaching content for pre-primary and primary pupils and to discuss the salient points of their in-class experience.

During the fourth year, student teachers spend 55 hours in a pre-primary classroom and 55 hours in a primary classroom planning learning units for different fields of experience and disciplines. The main objective of this fourth-year experience is to refine communicative learning competencies in teaching, and developing assessment skills. Another 65 hours is dedicated to monthly meetings with a mentor to learn how to document and record student work, and to discuss their in-class experience. During this year of training, students must attend seminars and meetings, and participate in European projects and other initiatives that will enhance their preparation in the field of pre-primary and primary education.

During the fifth year, student teachers spend 20 hours in a pre-primary classroom and 60 hours in a primary classroom where they plan laboratories for children and organize a class project. The main objective of the fifth year is to take on the role of teacher. Another 120 hours is dedicated to monthly meetings with a mentor to learn the use of technology in the classroom, the ethics of the teaching profession, and school rules and regulations. Student teachers share their in-class experience with a mentor for feedback.

The professional teacher training program, as designed in the Italian system, is instrumental in developing future teachers by offering hands-on experience as to the organization of the school, the curriculum, and the classroom. The future teacher is thus able to transition seamlessly from student to teacher from their first day in the classroom. 


\section{Conclusion}

In recent years, the formation of pre-primary and primary teachers has been prioritized by the Italian Ministry of Education. The program itself is designed to maximize success and is constantly being updated upon careful review. To allow for effective continuous professional development, the S.O.F.I.A. platform has been instituted to provide elective course offerings for teachers who wish to broaden their knowledge in various educational fields, including special education ${ }^{1}$. In addition, the Ministry of Education has more recently begun to actively support and, in some cases, subsidize those teachers seeking to obtain a first or a second level Master's degree in pre-primary or primary education. In Italy, pre-primary and primary teacher formation continues to evolve with the aim of providing well-trained and classroom-ready teaching professionals.

\section{References}

Catarci M. (2016). La pedagogia della liberazione di Paulo Freire.Educazione, intercultura e cambiamento sociale, FrancoAngeli: Milano.

Cervi M.A. Bonesso C. (2008). Emozioni per crescere. Come educare l'emotività, Armando: Roma 2008.

Freire P. (1971). La pedagogia degli oppressi, Mondadori: Milano.

MIUR (2012). Indicazioni nazionali per il curricolo della scuola dell'infanzia e del primo ciclo di istruzione, Le Monnier: Firenze.

Munari B. (1996). Da cosa nasce cosa: appunti per una metodologia progettuale, Laterza: Bari.

Munari B. (2006). Arte come mestiere, Laterza: Bari.

Munari B. (2017). Fantasia: invenzione, creatività e immaginazione nelle creazioni visive, Laterza: Bari.

Rosati N. (2015). Imparare in modo cooperativo. Strategie per l'inclusione, Multidea: Roma.

\section{ADDRESS FOR CORRESPONDENCE}

Nicoletta Rosati

Libera Universita Maria ss. Assunta di Roma, Italia e-mail: rosatinicoletta@lumsa.it

1 S.O.F.I.A.Sistema Operativo per la Formazione e le Iniziative di Aggiornamento dei docenti https:// sofia.istruzione.it/ last access June, 30th 2021 